\title{
ZrNO-Ag co-sputtered surfaces leading to E. coli inactivation under actinic light: Evidence for the oligodynamic effect
}

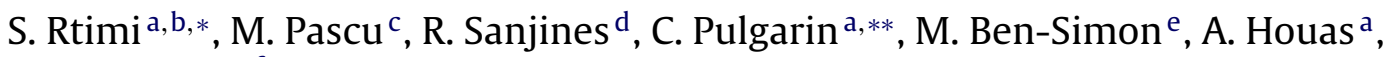 \\ J.-C. Lavanchy ${ }^{\mathrm{f}}$, J. Kiwi ${ }^{\mathrm{g}}$ \\ a UR Catalyse et Matériaux pour l'Environnement et les Procédés (URCMEP), Faculté des Sciences de Gabès, Université de Gabès, 6072,Gabès, Tunisia \\ ${ }^{\mathrm{b}}$ Ecole Polytechnique Fédérale de Lausanne, EPFL-SB-ISIC-GPAO, Station 6, CH-1015 -,Lausanne, Switzerland \\ ${ }^{c}$ Ecole Polytechnique Fédérale de Lausanne EPFL-BCH-LCS, 1015 Lausanne, Switzerland \\ d Ecole Polytechnique Fédérale de Lausanne, EPFL-SB-IPMC-LNNME, Bat PH, Station 3, CH-1015 Lausanne, Switzerland \\ e Ecole Polytechnique Fédérale de Lausanne, EPFL-ENAC-IIEGR-CEL, Bat GC, Station 18, CH-1015 Lausanne, Switzerland \\ ${ }^{\mathrm{f}}$ Université de Lausanne, IMG, Centre d'Analyse Minérale, Bat Anthropole, CH-1015 Lausanne, Switzerland \\ ${ }^{g}$ Ecole Polytechnique Fédérale de Lausanne, EPFL-SB-ISIC-LPI, Bat Chimie, Station 6, CH-1015 Lausanne, Switzerland
}

\section{A R T I C L E I N F O}

\section{Article history:}

Received 12 October 2012

Received in revised form 21 January 2013

Accepted 28 January 2013

Available online 21 February 2013

\section{Keywords:}

ZrNO sputtering

ZrNO-Ag co-sputtering

E. coli

Oligodynamic effect

\begin{abstract}
A B S T R A C T
This study reports visible light sensitive ZrNO and ZrNO-Ag polyester samples prepared by sputtering in an $\mathrm{Ar} / \mathrm{N}_{2} / \mathrm{O}_{2}$ atmosphere leading to Escherichia coli bacterial inactivation. The bacterial inactivation by $\mathrm{ZrNO}$ avoids the increasing environmental concern involving the fate of Ag-leaching of many disinfectants. The simultaneous co-sputtering of $\mathrm{ZrNO}$ and $\mathrm{Ag}_{2} \mathrm{O}$ enhanced the $E$. coli bacterial inactivation kinetics compared to the sequential sputtering of $\mathrm{ZrNO}$ and $\mathrm{Ag}$. A reaction mechanism is suggested triggered by photoinduced interfacial charge transfer (IFCT) suggesting electron injection form the $\mathrm{Ag}_{2} \mathrm{O}_{\mathrm{cb}}$ to the $\mathrm{ZrO}_{2 \mathrm{cb}}$. The sizes of the $\mathrm{ZrO}_{2}$ and Ag nanoparticles in the co-sputtered $\mathrm{ZrNO}-\mathrm{Ag}$ were $80-130 \mathrm{~nm}$ and $8-15 \mathrm{~nm}$ respectively as determined by high angular annular dark field (HAADF) microscopy. Evidence is presented by X-ray photoelectron spectroscopy (XPS) for the self-cleaning of the photocatalysts after bacterial inactivation. This enabled a stable catalyst reuse. The XPS experimental spectra of ZrNO and $\mathrm{ZrNO}-\mathrm{Ag}$ were deconvoluted into their $\mathrm{ZrN}, \mathrm{ZrNO}$ and $\mathrm{ZrO}_{2}$ components. The amounts of Ag-ions released during bacterial inactivation were $<5 \mathrm{ppb} / \mathrm{cm}^{2}$ and well below the Ag cytotoxic levels. Since no cytotoxicity was introduced during the bacterial inactivation process, the ZrNO-Ag disinfection proceeds through an oligodynamic effect.
\end{abstract}

(C) 2013 Elsevier B.V. All rights reserved.

\section{Introduction}

Antimicrobial nanoparticulate films preparation is a topic of increasing attention since their objective is to reduce or eliminate the formation of infectious bacteria biofilms leading to hospital acquired infections (HAI) [1-4]. But more effective bacterial inactivation are needed due to the increasing resistance of pathogenic bacteria to synthetic antibiotics administered for long times [5]. Also nosocomial infections due to antibiotic resistant bacteria are becoming more frequent developing into a serious problem associated with high health care costs. Recently, Mills et al. [6], Parkin et al. [7-10], Foster et al. [11], Dunlop et al. [12] and Yates et al.

\footnotetext{
* Corresponding author at: Ecole Polytechnique Fédérale de Lausanne, EPFL-SB-ISIC-GPAO, Station 6, CH-1015 Lausanne, Switzerland. Tel.: +41 216936150. ** Corresponding author at: Ecole Polytechnique Fédérale de Lausanne, EPFL-SB-ISIC-GPAO, Station 6, CH-1015 Lausanne, Switzerland. Tel.: +41 216934720.

E-mail address: sami.rtimi@epfl.ch (S. Rtimi).
}

[13] have reported antibacterial $\mathrm{Ag}, \mathrm{Cu}$, and $\mathrm{TiO}_{2}$ coatings on glass and polymer films depositing the metal/oxides by CVD and sputtering techniques. Our laboratory has reported the antibacterial properties and kinetics of Ag- and Cu-modified textiles deposited by DC-magnetron, pulsed DC-magnetron and high power impulse magnetron sputtering (HIPIMS). Kelly has reported TiN and other nitrides co-sputtered with Ag able to inactivate Gram-negative and Gram-positive bacteria in the dark $[14,15]$.

The benefits of the ZrNO films obtained by DC-sputtering in a reactive environment (in the presence of $\mathrm{O}_{2}$ ) compared the colloidal prepared films is in the microstructure of the films showing: uniformity, ability to control of the film thickness, improved adhesion and frequently fast bacterial inactivation kinetics. Colloidal deposited $\mathrm{TiO}_{2}$ films are non-uniform, not mechanically stable present low adhesion and can be wiped off by using a cloth or a thumb [16].

Another benefit found when using $\mathrm{ZrNO}$ and $\mathrm{ZrNO}-\mathrm{Ag}$ films is due to the nitride absorption in the visible range. This avoids doping like in the $\mathrm{TiO}_{2}$ to extend the $\mathrm{TiO}_{2}$ absorption into the visible region. 
Doping decreases considerably the photo-activity of the films compared to pristine $\mathrm{TiO}_{2}$ [17-19].

In the last section of the present study, the mechanism of the bacterial inactivation mediated by $\mathrm{ZrNO}-\mathrm{Ag}$ is discussed. Recently, we have reported the mechanism of the damage induced by $\mathrm{TiO}_{2}$ photocatalysis on the bilayer cell-envelope of Escherichia coli in several studies [20-23]. Other groups working in the disinfection field have also addressed the mechanism of disinfection [24-27]. The E. coli and MRSA viability as a function of time was monitored by direct transfer on plate and by stereomicroscopy. These two methods were used to determine the bacterial viability because they imply a very low experimental bias $[28,29]$. No bacterial regrowth was observed after bacterial inactivation. showing that the bacterial cells were not more viable.

The electronic properties of transition-metal oxy-nitrides $(\mathrm{MeO} x \mathrm{~N} y)$ in general and the optical properties like zirconium oxynitrides $(\mathrm{ZrO} x \mathrm{Ny})$ in particular have recently attracted considerable interest. These materials are used as gate dielectrics [30] temperature sensors in magnetic fields [31], corrosion resistance coatings [32] and decorative films (golden, gray and black tones) $[33,34]$. But these oxynitrides have been poorly explored for the inactivation of micro-organisms/bacteria. $\mathrm{ZrO}_{2}$ is a material with a band-gap of $5.0 \mathrm{eV}$ and a flat band potential of $-1.0 \mathrm{eV}$ vs NHE more negative than the potential $\mathrm{H}_{2} / \mathrm{H}_{2} \mathrm{O}$. Its valence hole potential is more positive than $1.23 \mathrm{eV} \mathrm{NHE}, \mathrm{pH} 0$ required for $\mathrm{O}_{2} / \mathrm{H}_{2} \mathrm{O}$. The band-gap for $\mathrm{ZrO}_{2}$ nanoparticles is 3.2 and $3.0 \mathrm{eV}$ [35]. Defects in their structure have been reported to play a role in $\mathrm{ZrO}_{2}$ donor to acceptor electron transfer reactions [36].

Our laboratory has recently published studies involving nitrides and oxy-nitrides [37]. Catalytic and photocatalytic disinfection of bacteria was reported using nitride sputtered samples. Reactive sputtering in the presence of $\mathrm{O}_{2}$ introduces ionic metal-oxygen species in an $\mathrm{N}$-matrix. $\mathrm{ZrO}_{2}$ is a photosensitive oxide and the trapping of the carriers induced by light has been shown to be important during bacterial inactivation.

Antimicrobial Ag-nanoparticles (NPs) have sputtered $[9,18,28,29]$ on different textiles due to the known disinfecting properties of Ag. Ag is also used in healing wound-pads [4-6], and implants [1]. The Ag-ions on responsible for the bacterial disinfection diffuse through the bacteria cell wall porins into the cell interior, leading to bacterial disinfection without inducing cytotoxicity. The bactericidal mechanism of Ag-ions implying: (i) condensation of DNA affecting bacterial replication, and (ii) interaction with protein-thiol groups leading to protein damage.

Magnetron sputtering has been used to deposit thin metal/oxide films (or combinations thereof) inducing self-cleaning and antibacterial properties in natural fibers like cotton and artificial textiles like polyester [14,15,28,29,37]. The present study addresses: (a) the sputtering of ZrNO and $\mathrm{ZrNO}-\mathrm{Ag}$ films on polyester optimizing the sputtering chamber gas atmosphere to attain the fastest $E$. coli bacterial inactivation kinetics, (b) the performance of $\mathrm{ZrNO}-\mathrm{Ag}$ films obtained either by sputtering sequentially $\mathrm{Ag}$ after $\mathrm{Zr}$ or by co-sputtering of both components, (c) the bacterial inactivation kinetics by $\mathrm{ZrNO}$ and $\mathrm{ZrNO}-\mathrm{Ag}$ films under low intensity actinic light and finally (d) the characterization of the microstructure of ZrNO and ZrNO-Ag films by X-ray fluorescence (XRF), diffuse reflectance spectroscopy (DRS), atomic force microscopy (AFM), contact angle (CA) and transmission electron microscopy (TEM).

\section{Experimental}

\section{1. $D C$ and $D C P$ sputtering procedures}

DC-magnetron sputtering of metals/oxides and semiconductor particulate has been carried out on textiles in our laboratory [37]. In the sputtering chamber the pressure was set at $0.1 \mathrm{~Pa}$ and the substrate-to-target distance was $10 \mathrm{~cm}$. Before the deposition of the films the residual pressure $\operatorname{Pr}$ in the sputtering chamber was $\operatorname{Pr} \leq 10^{-4} \mathrm{~Pa}$. The two inches diameter or $5 \mathrm{~cm} \mathrm{Zr}$-cathode was obtained from Lesker Corp, Hastings, East Sussex, UK. During the deposition of ZrNO on the polyester, we determined the most appropriate gas composition being: $5 \% \mathrm{~N}_{2}: 5 \% \mathrm{O}_{2}: 90 \%$ Ar. We varied the \% gas flow of $\mathrm{N}_{2}$ and $\mathrm{O}_{2}$ maintaining at a fix value the flow of Ar. The gas composition of $5 \% \mathrm{~N}_{2}: 5 \% \mathrm{O}_{2}: 90 \%$ Ar allowed to prepare the $\mathrm{ZrNO}-\mathrm{Ag}$ coatings sputtering for $90 \mathrm{~s}$ leading to the shortest time to attain total loss of bacterial viability ( $40 \mathrm{~min}$, as shown in Fig. 1c).

Oxygen is more reactive than nitrogen. Due to the higher $\mathrm{O}_{2}$ reactivity, the addition of $\mathrm{O}_{2}$ to a sputtered nitride film induces a different microstructure for the metal-bonds in the matrix of the covalent metal-nitrogen bond [14,15]. The effect of $\mathrm{O}_{2}$ concentration is reflected in the color of the nitride samples sputtered during this study. The $\mathrm{Zr}$ DC-sputtering was carried out at $280 \mathrm{~mA}$ and a bias voltage of $-330 \mathrm{~V}(90 \mathrm{~W})$. The polyester samples were $2 \mathrm{~cm} \times 2 \mathrm{~cm}$ in size. Four polyester squares $2 \mathrm{~cm} \times 2 \mathrm{~cm}$ were mounted in a round support, receiving the incoming sputtered particles in an homogeneous way as verified in many systems in our laboratory.

Direct current pulsed magnetron sputtering (DCP) was used to sputter $\mathrm{Ag}$ on $\mathrm{ZrNO}$ at $50 \mathrm{kHz}$ with a $15 \%$ reversed voltage. The DCP-sputtering consisted of continuous pulses of $10 \mu \mathrm{s}(280 \mathrm{~mA}$, $198 \mathrm{~W})$. The bias voltage was $-500 \mathrm{~V}$ during $\mathrm{ZrNO}$ deposition and then switched to $+75 \mathrm{~V}$ during $\mathrm{Ag}$ deposition (15\% of $-500 \mathrm{~V}$ ). The co-sputtering of $\mathrm{Zr}$ and $\mathrm{Ag}$ was carried out in a way was similar to the one recently reported [37].

The polyester was a Eidgenössiche Material und Prüfungs Anstalt (EMPA) test cloth sample No. 407, $130 \mu \mathrm{m}$ thick. It is a polyester Dacron polyethylene-terephthalate; type 54 spun, plain weave ISO 105-F04 used for color fastness determinations. The thermal stability of Dacron polyethylene terephthalate was $115^{\circ} \mathrm{C}$ for long-range operation and $140^{\circ} \mathrm{C}$ for times $\leq 1 \mathrm{~min}$.

The calibration of films thickness by the DC-sputtering of the ZrNO layers and DCP-sputtering of $\mathrm{Ag}$ on Si-wafers were determined with a profilometer (Alphastep500, TENCOR) and the experimental values were in error of $\pm 10 \%$.

\subsection{X-ray fluorescence determination of $\mathrm{Ag}$ and $\mathrm{Zr}$ content on polyester}

The Ag- and Zr-content of the polyester was evaluated by X-ray fluorescence in a PANalytical PW2400 spectrometer.

\subsection{Evaluation of the loss of bacterial}

The samples of Escherichia coli (E. coli K12) was obtained from the Deutsche Sammlung von Mikro-organismen und Zellkulturen GmbH (DSMZ) ATCC23716, Braunschweig, Germany to test the loss of bacterial viability on the Ag-polyester as previously reported by our laboratory $[21,28,37]$. The bacterial data reported were replicated three times. To verify that no re-growth of E. coli occurs after the first inactivation cycle, the $\mathrm{ZrNO}-\mathrm{Ag}$ samples were incubated for $24 \mathrm{~h}$ at $37^{\circ} \mathrm{C}$. Then the bacterial suspension of $100 \mu \mathrm{L}$ was deposited on three Petri dishes to obtain the replica samples for the bacterial counting. The bacterial counting data reported were replicated three times. No bacterial re-growth was observed.

The statistical analysis of the results was performed for the decrease of the bacterial CFU values reporting the standard deviation values for the runs showing the fastest bacterial inactivation.

The removal of the inoculated bacteria was tested by incubation of the sample on a Petri dish. After $24 \mathrm{~h}$ at $37^{\circ} \mathrm{C}$, very few colonies (1-7 colonies) or $99.9 \%$ of the inoculated bacteria were extracted and transferred from the polyester fabric into the saline solution. 

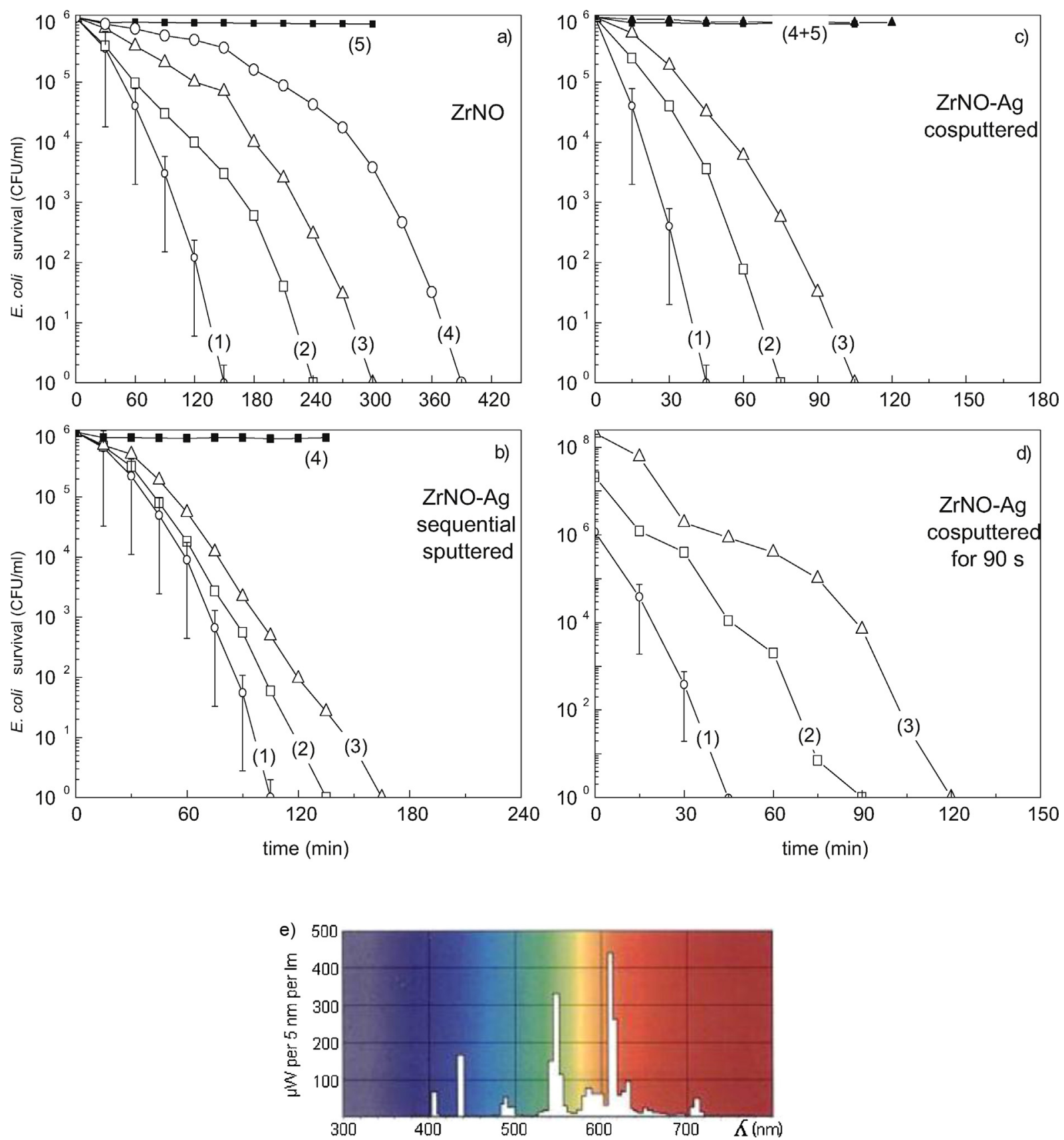

Fig. 1. (a) E. coli loss of viability by ZrNO as a function of time for: (1) Zr sputtered for $90 \mathrm{~s}$ on polyester; (2) Zr sputtered for $150 \mathrm{~s}$; (3) $\mathrm{Zr}$ sputtered for $60 \mathrm{~s}$; (4) $\mathrm{Zr}$ sputtered for $40 \mathrm{~s}$, The samples were irradiated with an Osram Lumilux 18/827 actinic lamp and finally (5) $\mathrm{Zr}$ sputtered for $90 \mathrm{~s}$ on polyester but in dark runs. (b) $\mathrm{Zr}$ sputtered on polyester for 90 s, followed by Ag-deposition for: (1) Ag 10 s; (2) Ag 20 s; (3) Ag 40 s, under Osram Lumilux 18/827 actinic lamp irradiation and finally (4) $\mathrm{Zr}$ sputtered on polyester for $90 \mathrm{~s}$ showing the loss of viability. (c) ZrNO-Ag co-sputtered on polyester (1) for $90 \mathrm{~s}$; (2) for $60 \mathrm{~s}$ and (3) for $150 \mathrm{~s}$. Runs under illumination under an Osram Lumilux $18 / 827$ actinic light, (4) Zr sputtered on polyester for $90 \mathrm{~s}$ in the dark and (5) polyester alone. (d) Effect of the initial concentration on the loss of viability of $E$. coli on a cosputtered ZrNO-Ag (90 s) sample under an Osram Lumilux 18/827 light. (e) Emission spectrum of the Osram Lumilux 18 W/827 lamp.

\subsection{Diffuse reflectance spectroscopy of polyester samples}

Diffuse reflectance spectroscopy was carried out using a Perkin Elmer Lambda 900 UV-VIS-NIR spectrometer provided for with a PELA-1000 accessory within the wavelength range of $200-800 \mathrm{~nm}$ having a resolution of $1.0 \mathrm{~nm}$. The absorption spectra of the samples were plotted in Kubelka-Munk (KM) arbitrary unit vs wavelength.

\subsection{Light irradiation source}

The irradiation of polyester samples was carried out in a closed cavity by Osram Lumilux $18 \mathrm{~W} / 827$ actinic lamps emitting between
400 and $700 \mathrm{~nm}$. Each lamp had an integral output of $1.2 \mathrm{~mW} / \mathrm{cm}^{2}$ resembling the light distribution in the solar irradiation. These actinic lamps are used generally in hospitals emitting light in the visible region and provide an efficient compromise of energy consumption per unit of luminous flux.

\subsection{Inductively coupled plasma sector field mass spectrometry (ICPS-MS)}

The FinniganTM ICPS used was equipped with a double focusing reverse geometry mass spectrometer with an extremely low background signal and a high ion-transmission coefficient. The spectral 
signal resolution was $1.2 \times 10^{5} \mathrm{cps} / \mathrm{ppb}$ and a detection limit of $0.2 \mathrm{ng} / \mathrm{L}$.

\subsection{X-ray photoelectron spectroscopy (XPS) of the sputtered samples}

An AXIS NOVA photoelectron spectrometer (Kratos Analytical, Manchester, UK) equipped with monochromatic Al $\mathrm{K} \alpha$ $(h v=1486.6 \mathrm{eV})$ anode was used during the study. The electrostatic charge effects on the samples were compensated by means of the low-energy electron source working in combination with a magnetic immersion lens. The quantitative surface atomic concentration of some elements was determined from peak areas using sensitivity factors and spectrum corrections [42]. The XPS spectra for the $\mathrm{Ag}$ - and $\mathrm{Zr}$-species were analyzed by means of spectra deconvolution software (CasaXPS-Vision 2, Kratos Analytical, UK).

\subsection{Transmission electron microscopy (TEM) of ZrNO-Ag samples}

A Philips CM-12 (field emission gun, $300 \mathrm{kV}, 0.17 \mathrm{~nm}$ resolution) microscope at $120 \mathrm{kV}$ was used to measure grain size of the $\mathrm{Ag}$ films. The textiles were embedded in epoxy resin 45359 Fluka and the fabrics were cross-sectioned with an ultramicrotome (Ultracut E) at a knife cutting angle of $35^{\circ}$. The energy-diffuse X-ray spectroscopy (EDX) images of the ZrNO-Ag samples were obtained by high angular annular dark field imaging (HAADF).

\section{Results and discussion}

\subsection{Thickness of Ag, ZrNO and ZrNO-Ag films on polyester}

DCP sputtering Ag-ions on polyester led within $1 \mathrm{~s}$ to a thickness of $1.2 \mathrm{~nm} \pm 10 \%$ equivalent to $\sim 5$ layers $0.2 \mathrm{~nm}$ thick. The rate of deposition of $\mathrm{Ag}$ is $5 \times 10^{15}$ atoms $/ \mathrm{cm}^{2} \mathrm{~s}$ if taking in the lattice the distance of $0.3 \mathrm{~nm}$ between $\mathrm{Ag}$-atoms [29]. A film obtained by sputtering is always less dense than the bulk material, so probably the indicated thickness is lower than the real thickness.

A ZrNO-coating thickness of $120 \mathrm{~nm}$ was sputtered within $90 \mathrm{~s}$ at $280 \mathrm{~mA}$. The co-sputtered $\mathrm{Zr}-\mathrm{Ag}$ layers leads to a $180 \mathrm{~nm}$ thickness within $90 \mathrm{~s}$. This film is thinner than the film obtained by sputtering sequentially $\mathrm{Ag}$ on $\mathrm{ZrNO}$ on polyester indicating the formation of hybrid composite $\mathrm{Zr}-\mathrm{Ag}$ layers.

\subsection{Bacterial inactivation on $\mathrm{ZrNO}$ and $\mathrm{ZrNO}-\mathrm{Ag}$-polyester}

Fig. 1a shows that ZrNO-sputtered polyester samples under low intensity actinic light $\left(4 \mathrm{~mW} / \mathrm{cm}^{2}\right)$ within $150 \mathrm{~min}$ a bacterial reduction from $10^{6} \mathrm{CFU} / \mathrm{ml}$ to undetected bacteria. Fig. 1a, trace 1 includes the statistical analysis of the data for the sample leading to the fastest inactivation as described in Section 2. No re-growth was observed after the first inactivation cycle for $\mathrm{ZrNO}$ and $\mathrm{ZrNO}-\mathrm{Ag}$ materials using the CFU monitoring methods described in Section 2.

Fig. 1b shows that the bacterial inactivation of $E$. coli by ZrNO-Ag samples under low intensity actinic light. Within $\sim 115 \mathrm{~min}$ a bacterial reduction from $10^{6} \mathrm{CFU} / \mathrm{ml}$ to undetected bacteria was observed. Only marginal improvement was observed in the bacterial inactivation kinetics in Fig. 1b compared to Fig. 1a.

Fig. 1c shows that $\mathrm{ZrNO}-\mathrm{Ag}$ co-sputtered for $90 \mathrm{~s}$ on polyester leads to a $6 \log _{10}$ bacterial reduction within $45 \mathrm{~min}$. The cosputtered $\mathrm{ZrNO}-\mathrm{Ag}$ for $90 \mathrm{~s}$ lead to the loss of viability within $40-45$ min in Fig. 1c, trace 1 . This time to obtain the total loss of viability is much shorter compare to the time to the sequentially sputtered $\mathrm{ZrNO}(90 \mathrm{~s})-\mathrm{Ag}(10 \mathrm{~s})$ sample reporter in Fig. $1 \mathrm{~b}$.
Therefore, co-sputtering $\mathrm{Zr}-\mathrm{Ag}$ is shown to lead to a faster loss in the bacterial viability as seen in Fig. 1c.

The polyester fabrics were sterilized by autoclaving at $121^{\circ} \mathrm{C}$ for $2 \mathrm{~h}$. The $20 \mu \mathrm{L}$ culture aliquots with an initial concentration of about $10^{6} \mathrm{CFU} \mathrm{mL} \mathrm{m}^{-1}$ in $\mathrm{NaCl} / \mathrm{KCl}(\mathrm{pH} 7)$ were placed on coated and uncoated (control) polyester fabric. The samples were placed on Petri dishes provided with a lid to prevent evaporation. After each determination, the fabric was transferred into a sterile $2 \mathrm{~mL}$ Eppendorf tube containing $1 \mathrm{~mL}$ autoclaved $\mathrm{NaCl} / \mathrm{KCl}$ saline solution. This solution was subsequently mixed thoroughly using a Vortex for $3 \mathrm{~min}$. Serial dilutions were made in $\mathrm{NaCl} / \mathrm{KCl}$ solution. A $100-\mu \mathrm{L}$ sample of each dilution was pipetted onto a nutrient agar plate and spread over the plate using standard plate method.

The polyester is a micro-porous substrate and distributes the inoculum evenly on the $\mathrm{ZrNO}, \mathrm{ZrNO}-\mathrm{Ag}$ films without needing an adsorption stage. A well-dispersed non-heterogeneous contact is established between the sample and the bacterial solution. In Section 3.9 we suggest the mechanism for the photo-activated ZrNO, $\mathrm{ZrNO}-\mathrm{Ag}$ trigger interfacial charge transfer leading to the formation of reactive oxidative species leading to the bacterial loss of viability.

\subsection{X-ray fluorescence of ZrNO and ZrNO-Ag sputtered samples}

The Ag- and Zr-contents of the samples were determined by Xray fluorescence. The weight percentage of $\mathrm{Ag}$ for sputtering times of $10 \mathrm{~s}, 20 \mathrm{~s}$ and $30 \mathrm{~s}$, was $0.06,0.13$ and $0.14 \mathrm{wt} \% / \mathrm{wt}$ polyester, respectively. The weight percentage of $\mathrm{Zr}$ for sputtering times of $10 \mathrm{~s}, 20 \mathrm{~s}$ and $30 \mathrm{~s}$, was $0.096,0.108$ and $0.195 \mathrm{wt} \% / \mathrm{wt}$ polyester, respectively. The co-sputtered $\mathrm{ZrNO}-\mathrm{Ag}$ (90 s) sample had a $\mathrm{Zr}$ content of $0.06-\mathrm{wt} \% \mathrm{Zr} / \mathrm{wt}$ polyester besides an $\mathrm{Ag}-0.1 \mathrm{wt} \% \mathrm{Ag} / \mathrm{wt}$ polyester.

Samples with a higher Ag-loading allowed longer bacterial survival times. Fig. 1b shows that for sequential Ag sputtered samples, the inactivation time becomes slower when sputtering for 20 and $40 \mathrm{~s} \mathrm{Ag}$ on the base layer of ZrNO sputtered for $90 \mathrm{~s}$. The reason for the longer inactivation kinetics is that longer Ag sputtering times leads to a thicker coating of $\mathrm{Ag}$ on the $\mathrm{ZrNO}$ photoactive layers. This



Fig. 2. Diffuse reflectance spectra for $\mathrm{ZrNO}$ and $\mathrm{ZrNO}-\mathrm{Ag}$ sputtered on polyester for times as indicated in the figure legends. 
hinders the ZrNO photocatalytic contribution leading to the loss of E. coli viability.

Fig. 1c shows the faster inactivation kinetics for a $90 \mathrm{~s}$ cosputtered sample in trace 1 . Sputtering for only $60 \mathrm{~s}$ did not deposit enough catalyst layers to absorb the incident actinic light as shown in trace 2. A longer bacterial inactivation within $105 \mathrm{~min}$ (trace 3) was observed for co-sputtered samples for $150 \mathrm{~s}$. These samples showed a longer inactivation time due to the formation of darker $\mathrm{Ag}$-aggregates with a bigger size hindering the light absorption by ZrNO.

\subsection{Survival kinetics as a function of the initial concentration and light dose}

Fig. 1d shows the bacterial inactivation kinetics of $E$. coli on the co-sputtered ZrNO-Ag (90 s) sample with an initial CFU concentrations of: $10^{8}, 5 \times 10^{7}$ and $10^{6}$. It is readily seen that the inactivation of higher bacterial concentrations need longer time.
This observation makes it possible to exclude a strong absorption of E. coli K12 on the co-sputtered ZrNO-Ag (90 s) sample. Adsorption of $E$. coli on the $30 \mathrm{~nm}$ particles is not possible since the size of the ellipsoidal shape $E$. coli $\mathrm{K} 12$ is $\sim 1 \mu \mathrm{m}$ [118]. The bacterial inactivation kinetics mediated by co-sputtered $\mathrm{ZrNO}-\mathrm{Ag}(90 \mathrm{~s})$ samples, were carried out applying three different light doses from the Lumilux Osram $18 \mathrm{~W} / 827$ lamp. This indicated that the bacterial inactivation kinetics was strongly dependent on the applied light dose in the reactor cavity.

\subsection{Diffuse reflectance spectroscopy (DRS)}

Fig. 2 presents the sample DRS spectra in Kubelka-Munk units. The UV-vis reflectance rough data cannot be used directly to assess the absorption of the loaded polyester because of the large scattering contribution of polyester to the reflectance spectra. Normally it is assumed a weak dependence of the scattering $(\mathrm{S})$ on the wavelength when taking DRS spectra. The KM/S values in Fig. 2 allow the
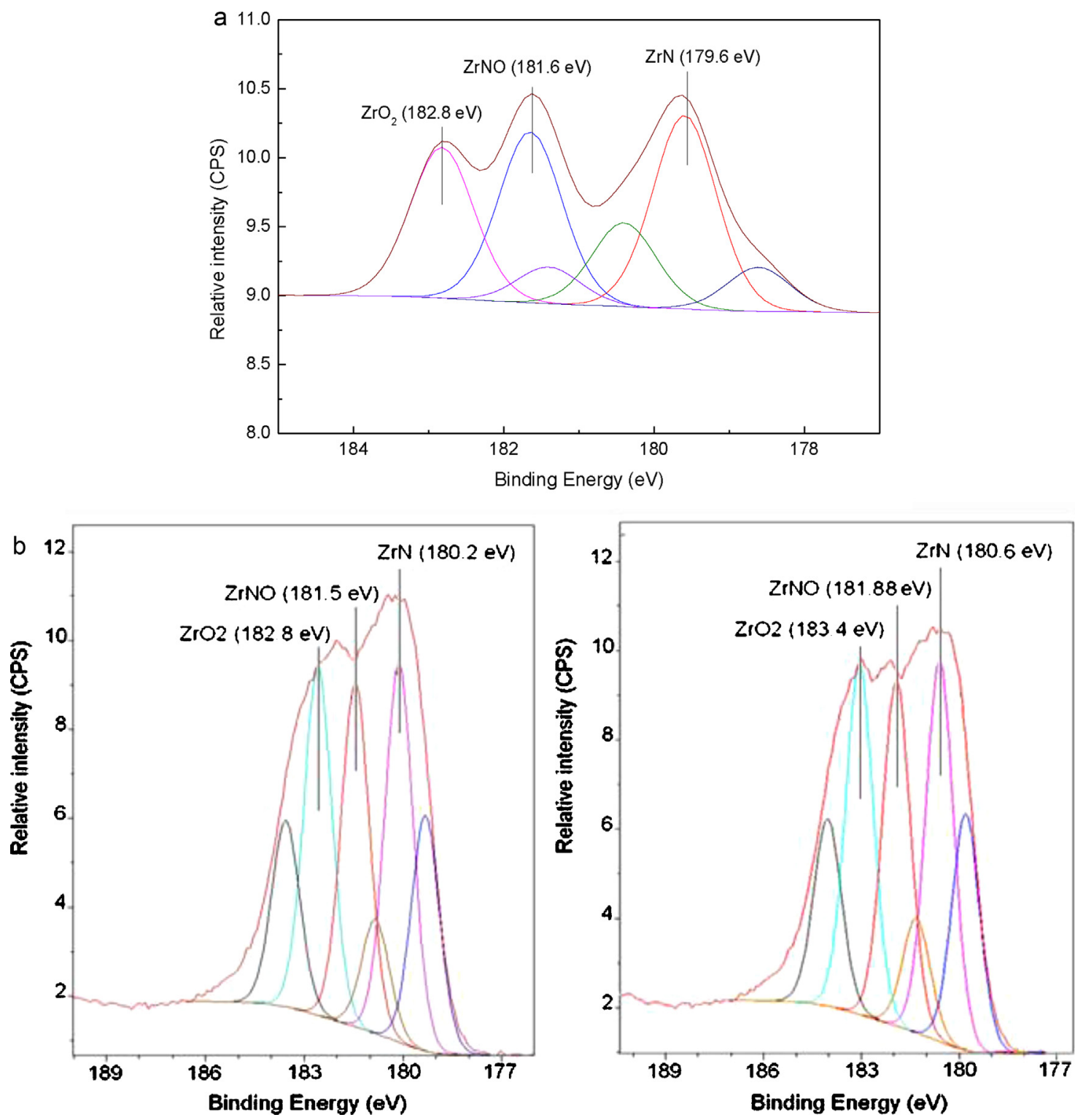

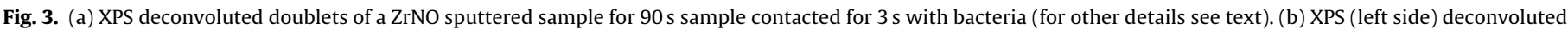

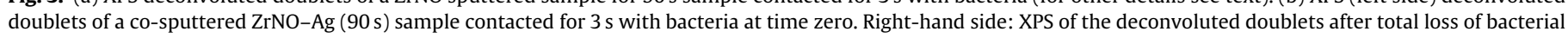
viability within $45 \mathrm{~min}$. 
Table 1

Surface atomic percentage concentration of elements of co-sputtered $\mathrm{ZrNO}-\mathrm{Ag}$ (90s).

\begin{tabular}{llllll}
\hline & O1s & N1s & C1s & Zr3d & Ag3d \\
\hline ZrNO/Ag (90 s) & 14.24 & 4.22 & 23.99 & 10.79 & 39.67
\end{tabular}

correlation of the spectral intensity of the ZrNO-Ag co-sputtered and of the ZrNO samples spectra with the bacterial inactivation kinetics shown in Fig. 1. The Increase in reflectance in the cosputtered spectra compared to the sequentially sputtered layers in Fig. 2 is due to the different microstructure of the $\mathrm{ZrNO}-\mathrm{Ag}$ photocatalyst in both cases as shown by TEM in Fig. 7 .

The red shifted absorption in the nanoparticles of $\mathrm{ZrNO}-\mathrm{Ag}$ show the appearance of a red tail in the DRS spectra of the nanoparticles in Fig. 2. Fig. 2 shows around $400 \mathrm{~nm}$ the localized surface resonance of the Ag-plasmons. Gunawan et al. [38] recently reported that the oxidation of silver from $\mathrm{Ag}^{0}$ to $\mathrm{Ag}_{2} \mathrm{O}$ is a reversible reaction increasing the surface plasmon resonance.

\subsection{XPS analysis of sputtered samples}

Fig. 3a shows the deconvoluted ZrNO sample sputtered $90 \mathrm{~s}$ on polyester and contacted for $3 \mathrm{~s}$ with bacteria. The experimental envelope was deconvoluted in three doublets by the CasaXPS Vision 2 software and the peaks assigned according to Wiame et al. [39] and Rizzo et al. [40] for: (a) ZrN at $179.6 .2 \mathrm{eV}$, (b) $\mathrm{ZrNO}$ at $181.6 \mathrm{eV}$ and (c) $\mathrm{ZrO}_{2}$ at $182.8 \mathrm{eV}$. The percentage areas of the deconvoluted peaks in the ZrNO experimental XPS envelope were: $\mathrm{ZrN} 35.37 \%$, $\mathrm{ZrNO} 33.76 \%$ and $\mathrm{ZrO}_{2} 30.87 \%$.

Fig. 3b shows the XPS envelope of the ZrNO-Ag co-sputtered (90 s) sample contacted $3 \mathrm{~s}$ with bacteria after 45 min leading to the total loss of viability. The deconvoluted peaks were found at: (a) $\mathrm{ZrN}, 180.2 \mathrm{eV}$, (b) $\mathrm{ZrNO}, 181.6 \mathrm{eV}$ and (c) $\mathrm{ZrO}_{2}, 182.8 \mathrm{eV}$. The percentage area in Fig. 3b were: $\mathrm{ZrN} 32.13 \%$, $\mathrm{ZrNO} 33.90 \%$ and $\mathrm{ZrO}_{2}$ $33.97 \%$ and were similar for $\mathrm{ZrNO}$ and $\mathrm{ZrNO}-\mathrm{Ag}$ samples. The $y$ axis shows that the counts intensity in the relative scale varies between 8 and 11 for the ZrNO samples and zero to 12 for the $\mathrm{ZrNnO}-\mathrm{Ag}$ samples. This reflects a stronger charge transfer in the ZrNO-Ag samples due to the Ag presence. We have determined the surface atomic percentage concentration of elements of $\mathrm{ZrNO}-\mathrm{Ag}$ co-sputtered (90 s) is shown in Table 1.

From Table 1, it can be seen that $\mathrm{Zr}$ represents only about $10 \%$ of the total composition of the topmost layers.

Fig. 4a shows a shift in the Ag3d for the $\mathrm{ZrNO}-\mathrm{Ag}$ co-sputtered (90 s) sample from a binding energy (BE) 364.7-365.4 eV within the $45 \mathrm{~min} E$. coli inactivation period. This reflects $\mathrm{Ag}^{1+} / \mathrm{Ag}^{2+}$ redox reactions taking place on the sample surface during the bacterial inactivation [41]. Fig. $4 \mathrm{~b}$ shows the $\mathrm{Zr}$-peak of the $\mathrm{ZrNO}-\mathrm{Ag}$ (90 s) sample shifting from a BE $181.6 \mathrm{eV}$ to a $\mathrm{BE} 182.7 \mathrm{eV}$ within the 45 min bacterial inactivation time, involving $\mathrm{Zr}^{4+} / \mathrm{Zr}^{3+}$ redox reactions when the sample interacts with bacteria [42].

\subsection{Sample reusability and ions release during bacterial inactivation detected by ICPS}

Fig. 5 shows the reuse of the co-sputtered ZrNO-Ag (90 s) sample during E. coli bacterial inactivation. Fig. 5 shows that after 8 cycles, the samples kept their initial performance. After the first and second recycling the discontinuity in the abscissa shows the non-sequential kinetics for the 4th and 8th recycling conserving the initial loss of viability kinetics. The inactivation bacterial time remained within $40-45$ min.

The surface atomic percentage concentration of elements in the ZrNO-Ag (90 s) sputtered samples after being contacted $3 \mathrm{~s}$ with bacteria were: O1s 8.8\%; N1s 2.3\%; C1s 54.9\%; Zr3d 2.8\% and Ag3d
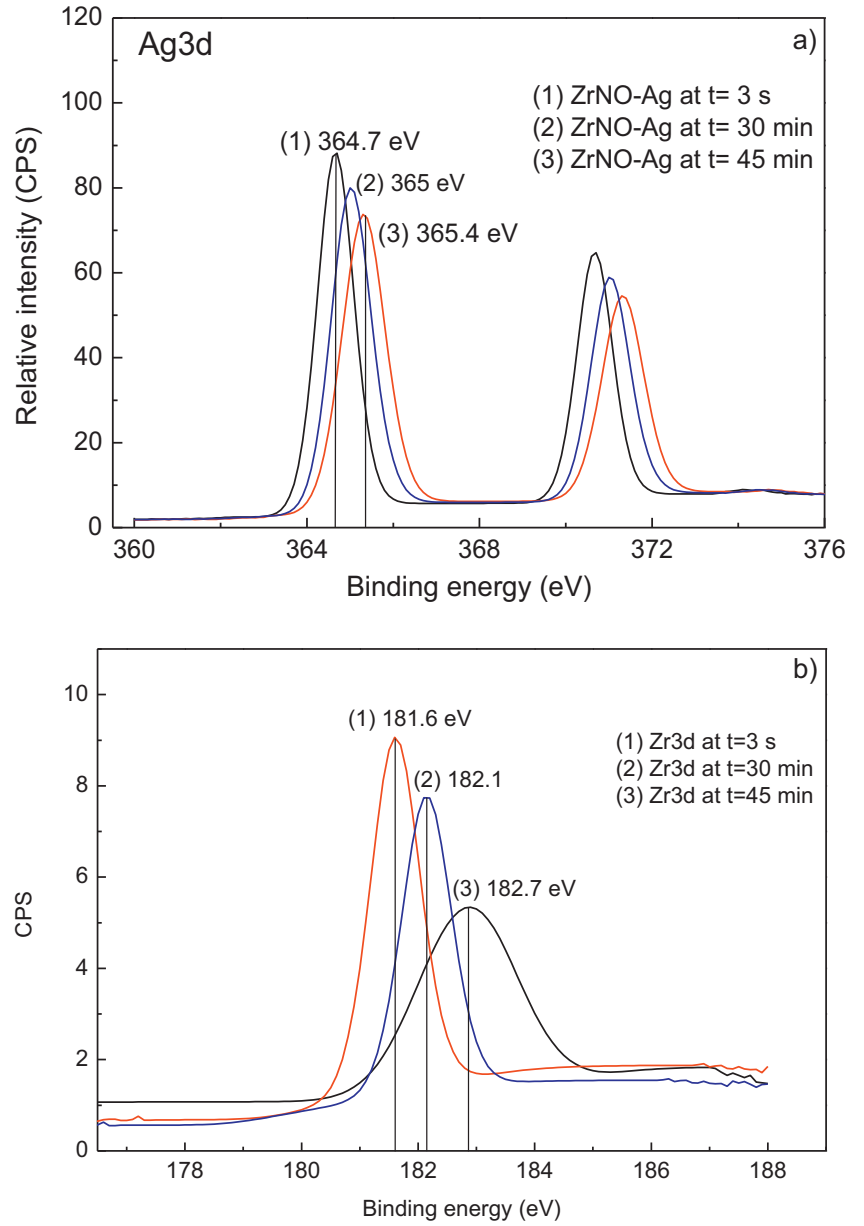

Fig. 4. (a) XPS shift of the Ag-doublets for the co-sputtered ZrNO-Ag (90 s) sample within the $45 \mathrm{~min}$ period of bacterial inactivation. (b) $\mathrm{Zr}$ peak-shift during $E$. col inactivation for the co-sputtered $\mathrm{ZrNO}-\mathrm{Ag}(90 \mathrm{~s})$ sample within the $45 \mathrm{~min}$ bacterial inactivation.

$35.4 \%$. These percentages did vary less than $10 \%$ during the $40 \mathrm{~min}$ reaction leading to the total bacterial loss of viability. Therefore, the rapid destruction of the fragments of bacterial decomposition during the photocatalysis accounts for the constant rate observed for the total loss of viability reported in Fig. 5.

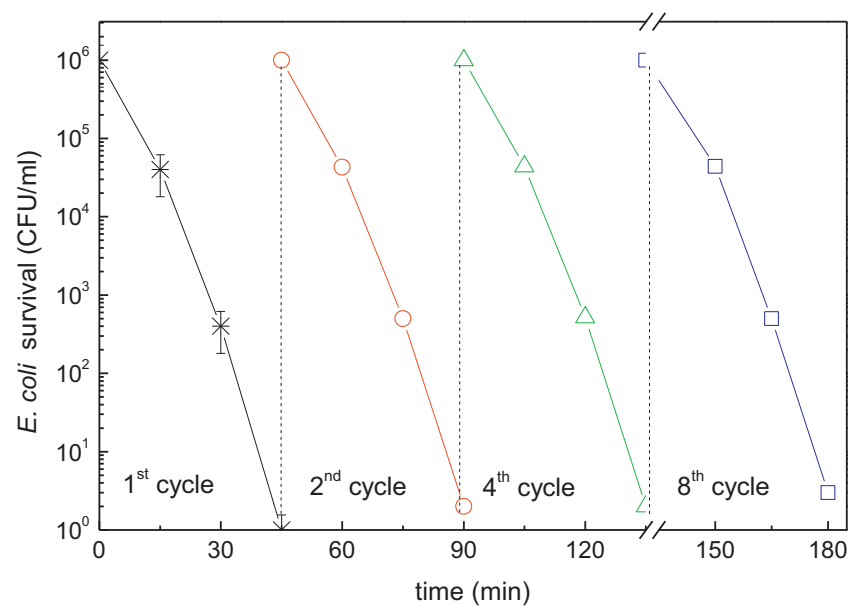

Fig. 5. Cycling of a ZrNO-Ag (90s) samples leading to the total loss of bacteria viability under Osram Lumilux $18 \mathrm{~W} / 827(400-700 \mathrm{~nm})$ irradiation. 


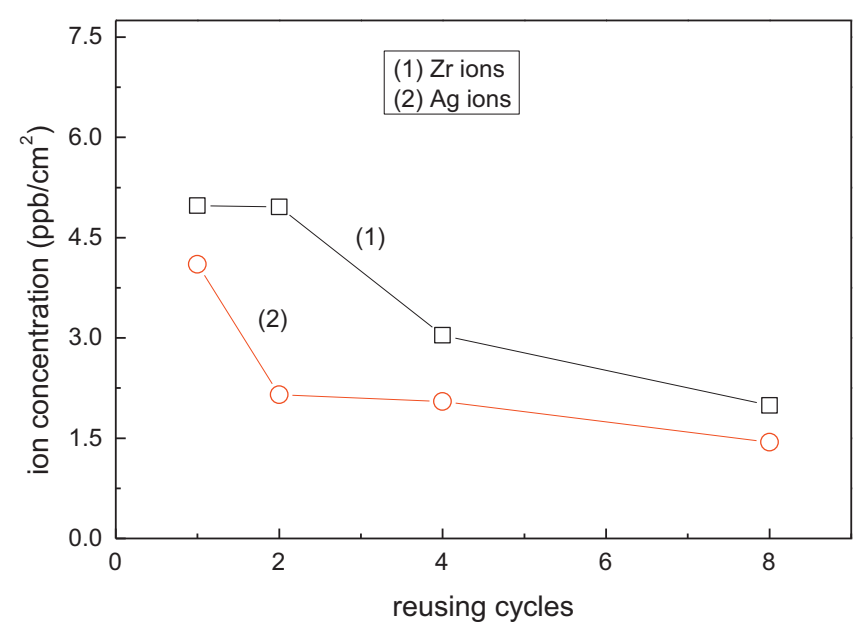

Fig. 6. Ion-coupled plasma mass spectrometry (ICP-MS) determination of Ag-ions and $\mathrm{Zr}$-ions released from a co-sputtered $\mathrm{ZrNO}-\mathrm{Ag}(90 \mathrm{~s})$ within the E. coli loss of bacterial viability.

Fig. 6 shows the Ag- and $\mathrm{Zr}$-ions concentrations released during the reuse of $\mathrm{ZrNO}-\mathrm{Ag}$ (90 s) sputtered samples. The Ag-ions release during 8 cycles was $<5 \mathrm{ppb} / \mathrm{cm}^{2}$, which is below the allowed cytotoxicity levels of $35-90 \mathrm{ppb} / \mathrm{cm}^{2}$ [43]. Therefore, the bacterial inactivation mediated by $\mathrm{ZrNO}-\mathrm{Ag}$ (90 s) does not introduce cytotoxicity but proceeds through an oligodynamic effect.

\subsection{Electron microscopy (TEM) and EDX of $\mathrm{ZrNO}-\mathrm{Ag}(90 \mathrm{~s})$ co-sputtered sample}

Fig. 7a presents the TEM of a co-sputtered ZrNO-Ag (90 s) sample on polyester. In the left-hand side the $\mathrm{Zr}$ and $\mathrm{Ag}$ are shown to be immiscible when co-sputtered on the polyester fibers. The righthand side Fig. 7a shows the $\mathrm{Zr}$ and $\mathrm{Ag}$-nanoparticles contrasted by high angular annular dark field (HAADF). The sizes of the $\mathrm{ZrO}_{2}$ and Ag nanoparticles in the co-sputtered $\mathrm{ZrNO}-\mathrm{Ag}$ (90 s) sample were respectively $80-130 \mathrm{~nm}$ and $8-15 \mathrm{~nm}$. Fig. $7 \mathrm{~b}$ presents the different microstructure to the one seen for the co-sputtered samples. Two well-defined bands of sequentially sputtered ZrNO (90 s) and $\mathrm{Ag}$ (20 s) were observed.

Due to its size, the Ag nanoparticles are not able to penetrate to bacteria core through the bacterial porins with diameters of $1-1.3 \mathrm{~nm}[44,45]$. Only Ag-ions diffuse through bacterial porins leading to DNA damage and finally to bacterial inactivation [9].

\subsection{Suggested reaction mechanism}

The $\mathrm{ZrO}_{2}$ species has been deconvoluted as described in the XPS section for the ZrNO-Ag (90 s) sample. All metals with exception of $\mathrm{Hg}$ are known to form surface hydroxide in contact with a

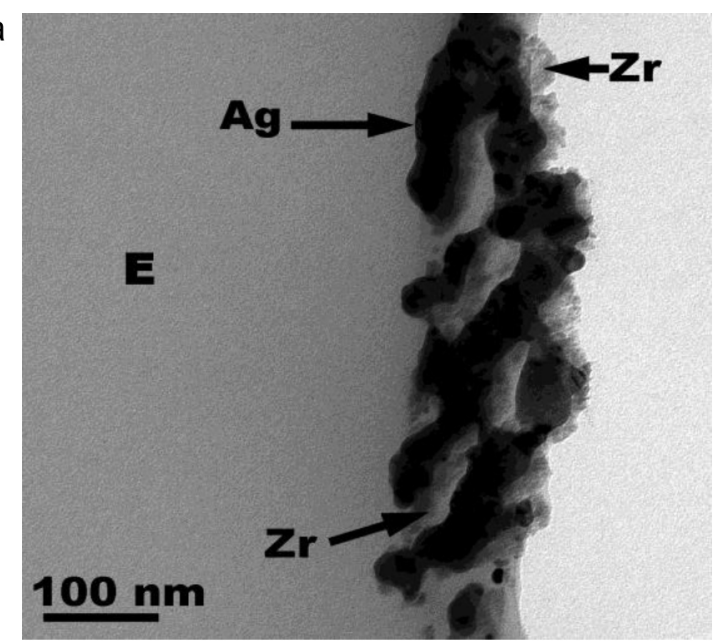

b

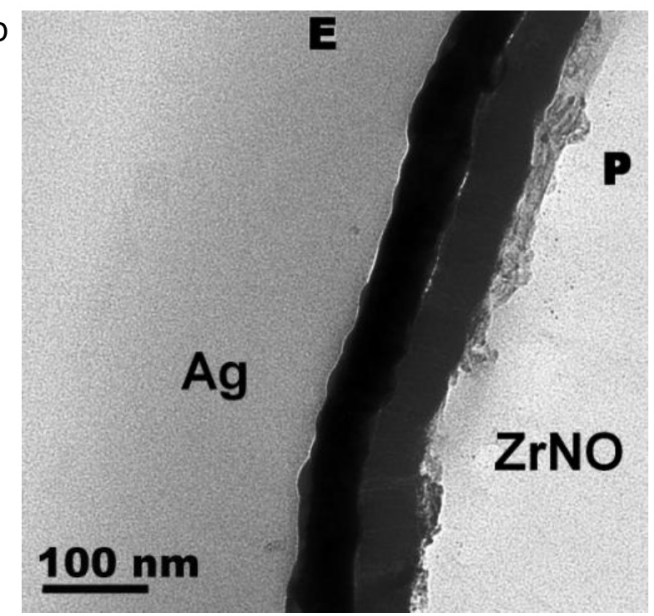

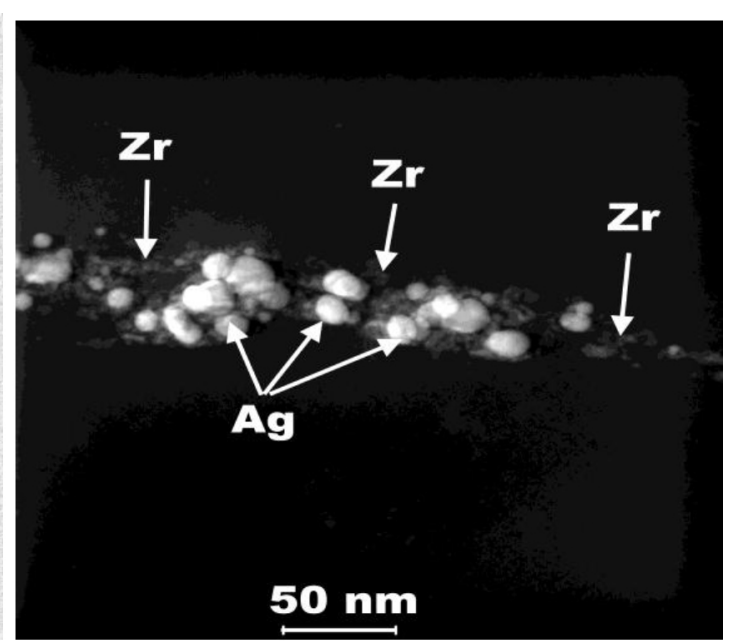

$50 \mathrm{~nm}$

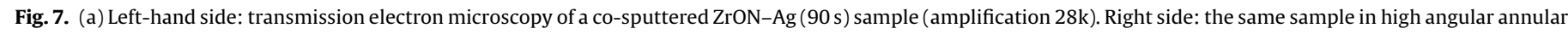
dark field (HAADF) representation. (b) EM of sequential sputtering of $\mathrm{ZrNO}$ (90 s) followed by sputtering of $\mathrm{Ag}$ ( $20 \mathrm{~s}$ ). 


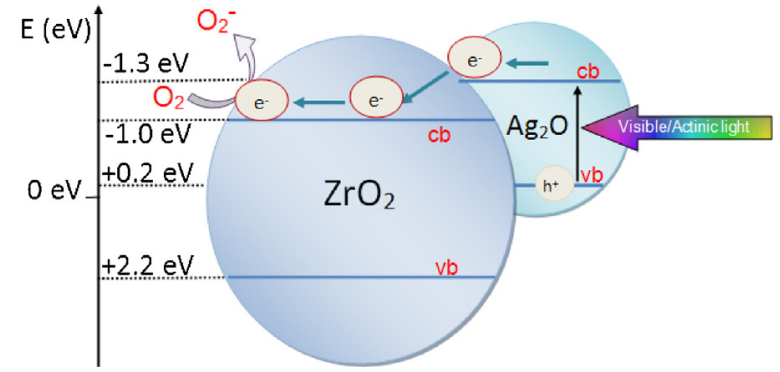

Fig. 8. Scheme of the electron injection from $\mathrm{Ag}_{2} \mathrm{O}$ to $\mathrm{ZrO}_{2}$ under visible light.

air containing water vapor. $\mathrm{ZrNO}-\mathrm{Ag}$ samples forms $\mathrm{AgOH}$ on its surface. The favorable decomposition of $\mathrm{AgOH}$ leads to $\mathrm{Ag}_{2} \mathrm{O}$ as in (Eq. (1)) [46].

$\mathrm{AgOH} \rightarrow \mathrm{Ag}_{2} \mathrm{O}+\mathrm{H}_{2} \mathrm{O}(\mathrm{pk}=2.87)$

$\mathrm{Ag}_{2} \mathrm{O}$ is thermodynamically stable at $\mathrm{pH} \mathrm{6-7} \mathrm{where} \mathrm{the} \mathrm{bac-}$ terial inactivation of $E$. coli is shown to proceed in Fig. 1a-c. For mechanistic considerations of the $\mathrm{ZrO}_{2} / \mathrm{Ag}_{2} \mathrm{O}$ under visible light we consider next the energy level of $\mathrm{Ag}_{2} \mathrm{O}$ and $\mathrm{ZrO}_{2}$. The $\mathrm{ZrO}_{2}$ nanoparticles in Fig. 7 present sizes of $\sim 100 \mathrm{~nm}$ and these nanoparticles have been reported with a band-gap (bg) 3.2 eV [35], a conduction band $(\mathrm{cb})$ at $-1.0 \mathrm{eV}$ NHE and a valence band $(\mathrm{vb})$ at $+2.2 \mathrm{eV}$ NHE [36]. Visible light photo-activates the semiconductor $\mathrm{Ag}_{2} \mathrm{O}$ with $1.46<\mathrm{bg}<2.25 \mathrm{eV}[47,48]$

$\mathrm{Ag}_{2} \mathrm{O}+$ light $\rightarrow \mathrm{Ag}_{2} \mathrm{O}\left(\mathrm{h}_{\mathrm{vb}}{ }^{+}\right)+\mathrm{Ag}_{2} \mathrm{O}\left(\mathrm{e}_{\mathrm{cb}}{ }^{-}\right)$

The bacterial inactivation kinetics reported in Fig. 1c suggests that the interfacial charge transfer process (IFCT) [49] in the cosputtered $\mathrm{ZrNO}-\mathrm{Ag}$ film proceeds more readily compared to the sequential sputtered ZrNO-Ag sample (Fig. 1b) due to the shorter distance between $\mathrm{Zr}$ and $\mathrm{Ag}$ inducing higher quantum efficiency. Donor-acceptor pair interactions depend on the charge diffusion distance and this is a function of the particle size and shape in the film microstructure.

Under visible light, the transfer of charge from $\mathrm{Ag}_{2} \mathrm{O}$ to $\mathrm{ZrO}_{2}$ is thermodynamically favorable. The $\mathrm{Ag}_{2} \mathrm{O}_{\mathrm{cb}}$ is $-1.3 \mathrm{eV} \mathrm{NHE}$ at pH 0 . The vb of $\mathrm{Ag}_{2} \mathrm{O}+0.2 \mathrm{eV}$ NHE at $\mathrm{pH} 0$ [47-49] lie above the $\mathrm{ZrO}_{2}$ presenting a conduction band $(\mathrm{cb})$ at $-1.0 \mathrm{eV}$ and the valence band $(\mathrm{vb})$ at $+2.2 \mathrm{eV}$. The electrons in the $\mathrm{Ag}_{2} \mathrm{O}_{\mathrm{cb}}$ inject electron into the $\mathrm{ZrO}_{2 \mathrm{cb}}$ since they are situated at a higher energetic level. The electrons in Eq. (2) react with $\mathrm{Ag}_{2} \mathrm{O}$

$2 \mathrm{Ag}_{2} \mathrm{O}+\mathrm{e}^{-} \rightarrow 4 \mathrm{Ag}^{0}+\mathrm{O}_{2}^{-}$

We suggest that $\mathrm{O}_{2}$ Eq. (3) promote the reactions (5) and (6) producing highly oxidative radicals, while the $\mathrm{h}^{+}$in Eq. (2) would react with $\mathrm{H}_{2} \mathrm{O}$ (water vapor) as shown below in Eq. (4). This reaction runs parallel with Eq. (5) generating $\mathrm{OH}^{\circ}$ radicals or other highly reactive oxidative radicals able to inactivate E. coli. The $\mathrm{h}_{\mathrm{vb}}{ }^{+}$in Eq. (4) originate from the $\mathrm{Ag}_{2} \mathrm{O}$ nanoparticles in Eq. (2)

$\mathrm{h}_{\mathrm{vb}}{ }^{+}+\mathrm{H}_{2} \mathrm{O} \rightarrow \mathrm{OH}^{\circ}+\mathrm{H}^{+}$

$\mathrm{e}_{\mathrm{cb}}{ }^{-}+\mathrm{H}_{2} \mathrm{O}+\mathrm{O}_{2} \rightarrow \mathrm{OH}^{\circ}+\mathrm{OH}^{-}+1 / 2 \mathrm{O}_{2}{ }^{-}$

$\mathrm{e}_{\mathrm{cb}}{ }^{-}+\mathrm{O}_{2} \rightarrow \mathrm{O}_{2}{ }^{\bullet-}$

We show in Fig. 8 a scheme for the charge transfer discussed in the preceding paragraphs to better visualize the photo-induced electron injection from $\mathrm{Ag}_{2} \mathrm{O}$ into $\mathrm{ZrO}_{2}$ induced under visible light.

\section{Conclusions}

Zr-oxynitride films on polyester have been deposited by sputtering methods. This study presents the effect of visible light induced processes on E. coli inactivation. The ZrNO-Ag XPS envelope was deconvoluted showing $\mathrm{ZrO}_{2}, \mathrm{ZrNO}$, and $\mathrm{ZrN}$. The most suitable bacterial inactivation under light was attained with the $\mathrm{ZrNO}-\mathrm{Ag}$ co-sputtered samples on polyester for $90 \mathrm{~s}$. Bacterial inactivation kinetics of $E$. coli depends on the amount of $\mathrm{Ag}$ on the polyester and if sequential or simultaneous sputtering of $\mathrm{ZrNO}$ and $\mathrm{Ag}$ was applied. The fasts co-sputtering of ZrNO and Ag presented a thickness below the addition of the individual $\mathrm{ZrNO}$ and Ag-layers obtained by sequential sputtering of $\mathrm{ZrNO}$ and $\mathrm{Ag}$. The repetitive bacterial inactivation the ZrNO-Ag polyester samples provided evidence for the stability and adhesion of the samples. The optical absorption of the $\mathrm{ZrNO}$ and $\mathrm{ZrNO}-\mathrm{Ag}$ samples was found to be directly proportional to the $E$. coli inactivation kinetics under low intensity actinic light. A possible reaction mechanism is suggested based on the energetic band levels of $\mathrm{Ag}_{2} \mathrm{O}$ and $\mathrm{ZrO}_{2}$. The $\mathrm{ZrNO}-$ sputtered polyester showed also a significant bactericide effect. This is important since these later surfaces avoid the leaching of the heavy Ag-metal into the environmental, a matter of growing environmental concern.

\section{Acknowledgments}

We thank the COST Action MP0804 Highly Ionized Impulse Plasma Processes (HIPIMS), the EPFL and LIMPID 7 FP Collaborative European Project Nanocomposite Materials for Photocatalytic Degradation of Pollutants NMP 2012.2.2.2-6 (n. 310177) for financial support of this work.

\section{References}

[1] Thüringer Surface and Biomaterials Kolloquium, 13-15 September 2011, Zeulenroda, Germany.

[2] J. Bourn, Improving patient care by reducing the risk of hospital acquired infection: A progress report, National Audit Office, 2003-2004.

[3] R. Plowman, R. Graves, N. Griffin, L. Taylor, Journal of Hospital Infection 47 (2001) 198-204.

[4] S. Dancer, Journal of Hospital Infection 73 (2009) 378-386.

[5] A. Kramer, I. Schwebke, G. Kampf, Diseases 6 (2006) 137-146.

[6] A. Mills, C. Hill, P. Robertson, Journal of Photochemistry and Photobiology A 237 (2012) 7-23.

[7] K. Page, M. Wilson, P.I. Parkin, Journal of Materials Chemistry 19 (2009) 3819-3831.

[8] S. Noimark, Ch Dunnill, M. Wilson, P.I. Parkin, Chemical Society Reviews 38 (2009) 3435-3448.

[9] C. Page, M. Wilson, N. Mordan, W. Chrzanowski, J. Knowles, P.I. Parkin, Journal of Materials Science 46 (2011) 6355-6363.

[10] K. Page, R. Palgrave, P.I. Parkin, M. Wilson, Sh. Savin, Journal of Materials Chemistry 17 (2007) 95-104.

[11] H.A. Foster, P. Sheel, W.D. Sheel, P. Evans, S. Varghese, N. Rutschke, M.H. Yates, Journal of Photochemistry and Photobiology A 216 (2010) 283-289.

[12] M.S.P. Dunlop, P.C. Sheeran, A.J.M. Byrne, S.A. McMahon, M.A. Boyle, G.K McGuigan, Journal of Photochemistry and Photobiology A 216 (2010) 303-3010.

[13] M.H. Yates, A.L. Brook, B.I. Ditta, P. Evans, H.A. Foster, D.W. Sheel, A. Steele Journal of Photochemistry and Photobiology A 197 (2008) 197-2008.

[14] P. Kelly, H. Li, P. Benson, K. Whitehead, J. Verran, R. Arnell, I. Iordanova, Surface \& Coatings Technology 205 (2010) 1606-1610.

[15] P. Kelly, H. Li, K. Whitehead, J. Verran, R. Arnell, I. Iordanova, Surface \& Coatings Technology 204 (2009) 1137-1141.

[16] L. Zhang, R. Dillert, D. Bahnemann, Energy \& Environmental Science 5 (2012) 7491-7507.

[17] A. Fujishima, T. Rao, D. Tryk, Journal of Photochemistry and Photobiology C: Reviews 1 (2009) 1-21.

[18] W. Tung, W. Daoud, Journal of Materials Chemistry 21 (2011) 7858-7869.

[19] P.V. Kamat, Accounts of Chemical Research 45 (2012) 1906-1915.

[20] J. Kiwi, V. Nadtochenko, Journal of Physical Chemistry B 108 (2004) $17675-17684$

[21] V. Nadtochenko, A. Rincon, S. Stanka, J. Kiwi, Journal of Photochemistry and Photobiology A 169 (2009) 131-137.

[22] R. Bacsa, J. Kiwi, T. Ohno, P. Albers, V. Nadtochenko, Journal of Physical Chemistry B 109 (2005) 5994-6003.

[23] J. Kiwi, V. Nadtochenko, Langmuir 21 (2005) 4631-4641.

[24] H. Foster, I. Ditta, S. Varghese, A. Steele, Applied Microbiology and Biotechnology 90 (20) (2013) 1847-1868.

[25] O.K. Dalrymple, E. Stefanakos, M. Trotz, D. Goswami, Applied Catalysis B: Environmental 98 (2010) 27-38. 
[26] S. Pigeot-Rémy, F. Simonet, E. Errazuriz-Cerda, J. Lazzaroni, D. Atlan, C. Guillard, Applied Catalysis B: Environmental 104 (2011) 390-398.

[27] A. Markowska-Szczupak, K. Ulfig, A. Morawski, Catalysis Today 169 (2011) 249-257.

[28] L. Rio, E. Kusiak, J. Kiwi, C. Pulgarin, A. Trampuz, A. Bizzini, Journal of Applied Microbiology 78 (2012) 8176-8182.

[29] K. Sarakinos, J. Alami, D. Konstantinidis, Surface \& Coatings Technology 204 (2010) 1661-1684.

[30] E. Nieh, C. Kang, H. Cho, K. Onishi, R. Choi, S. Krishnan, J. Han, Y. Kim, J. Akbar, C. Lee, IEEE Transactions on Electron Devices 50 (2003) 333-340.

[31] B. Brandt, D. Liu, L. Rubin, Review of Scientific Instruments 70 (1999) 104-110.

[32] E. Ariza, L.A. Rocha, F. Vaz, L. Cunha, S.C. Ferreira, P. Carvalho, L. Rebouta, E. Alves, Ph. Goudeau, J.P. Riviere, Thin Solid Films 469-470 (2004) 274-281.

[33] P. Carvalho, F. Vaz, L. Rebouta, L. Cunha, C.J. Tavares, C. Moura, E. Alves, A. Cavaleiro, Ph Goudeau, E. Le Bourhis, J.P. Rivière, J.F. Pierson, O. Banakh, Journal of Applied Physics 98 (2005) 023715.

[34] F. Vaz, P. Carvalho, L. Cunha, L. Rebouta, C. Moura, E. Alves, A.R. Ramos, A. Cavaleiro, Ph. Goudeau, J.P. Rivière, Thin Solid Films 469-470 (2004) 11-17.

[35] A. Emeline, G. Kateva, V. Rudakova, N. Ryabchuk, N. Serpone, Langmuir 14 (1998) 5011-5022.

[36] K. Sayama, H. Arakawa, Journal of Physical Chemistry 97 (1993) 531-533.

[37] S. Rtimi, O. Baghriche, R. Sanjines, C. Pulgarin, M. Ben-Simon, J.-C. Lavanchy, A. Houas, J. Kiwi, Applied Catalysis B: Environmental 123-124 (2012) 306-315.
[38] C. Gunawan, W. Teoh, C. Marquis, J. Lifia, R. Amal, Small 5 (2009) 341-347.

[39] H. Wiame, M. Centeno, M. Picard, S. Bastians, P. Grange, Journal of the European Ceramic Society 18 (1998) 1293-1927.

[40] A. Rizzo, M. Signore, L. Mirenghi, T. Di Luccio, Thin Solid Films 517 (2009) 5956-5964.

[41] M.-I. Mejía, G. Restrepo, M. Marín, R. Sanjinés, C. Pulgarín, J. Mielczarski, E. Mielczarski, J. Kiwi, ACS Applied Materials \& Interfaces 2 (2010) 230-235.

[42] D.C. Wagner, M.W. Riggs, L.E. Davis, G.E. Müllenberg (Eds.), Handbook of X-ray Photoelectron Spectroscopy, Perkin-Elmer Corp. Phys. Electr. Div., Minnesota, 1979.

[43] A. Ewald, S.K. Glückerman, R. Thull, U. Gbureck, Biomedical Engineering (Online) 5 (2006) 20-32.

[44] H. Nikaido, The Journal of Biological Chemistry 269 (1994) 3905-3908.

[45] P. Asharani, G. Mun, M. Hande, V. Valiyavettil, ACS Nano 3 (2009) 279-290.

[46] M. Pourbaix, Atlas of Electrochemical Equilibria in Aqueous Solutions, NACE Int Texas, USA, 1976

[47] Y. Ida, T. Watase, M. Shinagawa, M. Watabanbe, M. Chigane, M. Inaba, A. Tasaka, M. Izaki, Chemistry of Materials 20 (2008) 1254-1256.

[48] A. Varkey, Solar Energy Materials and Solar Cells 29 (1993) 253-259.

[49] H. Irie, S. Miura, K. Kamiya, K. Hashimoto, Chemical Physics Letters 457 (2008) 202-207. 